\title{
A fast growing sternal mass
}

\section{George A Demetriou, ${ }_{1}^{1}$ Michalis Marcou, ${ }^{2}$ Andreas Demetriou, ${ }^{3}$ Christos Kyriakides ${ }^{4}$}

${ }^{1}$ North Middlesex University Hospital, London, UK ${ }^{2}$ Department of General Surgery, St'George's Private Hospital, Pafos, Cyprus

${ }^{3}$ Department of Internal Medicine and Cardiology, St'Georges's Private Hospital, Pafos, Cyprus

${ }^{4}$ Department of Neurosurgery, St'George's Private Hospital, Pafos, Cyprus

Correspondence to Dr George A Demetriou, gdemcy@hotmail.com
To cite: Demetriou GA, Marcou M, Demetriou A, et al. BMJ Case Rep Published online: [please include Day Month Year] doi:10.1136/bcr-2013008673

\section{DESCRIPTION}

An 80-year-old man, presented with local relapse, bony and lung metastasis 1 year following a resection of a sacral chordoma. He required chemotherapy and several procedures for improving his neurological symptoms in the cervical, thoracic and sacral vertebrae. Chordoma was diagnosed based on the morphological and immunohistochemistry results, which showed positive CK-8, CK-19, S-100, cadherin and negative CK-7 and CK-20.

At the same time an anterior $9 \times 11 \times 15 \mathrm{~cm}$ sternal mass was noticed (figures 1 and 2). The CT of the chest (figure 3) showed that it was compressing the right atrium and had multiple smaller lesions in the lungs and thoracic vertebrae. A CT of the abdomen and pelvis was normal apart from a cyst in the right kidney, which was the same size as from a previous scan. The tumour was not operated owing to the extensive bony and soft tissue destruction of the anterior chest wall and the involvement of right atrium and also because of the extent of the metastatic disease. It was therefore not biopsied.

Chordoma are malignant tumours arising from the primitive notochord remnants. A total of $49 \%$ arise from sacrococcygeal, $36 \%$ from cranial, nasopharyngeal and spheno-occipital and 15\% from vertebral regions. ${ }^{1}$ They can be locally destructive and tend to recur but have low potential of metastasis. However, disseminated metastatic disease has been reported in the literature and mostly occurs from primaries in sacrococcygeal region. ${ }^{1}$ The chest wall metastasis was reported only twice. ${ }^{2}$ In our case the history and image findings suggest that even though it had never been proven by histology, the possibility of sternal chordoma is most likely the case.

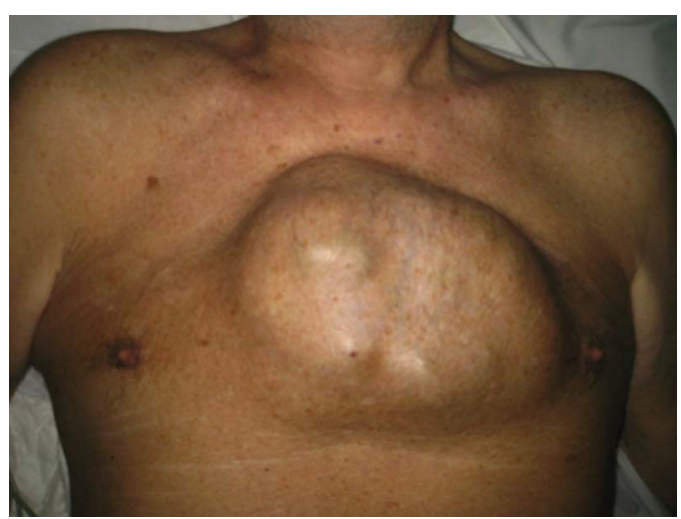

Figure 1 A picture of the sternal mass from the front.

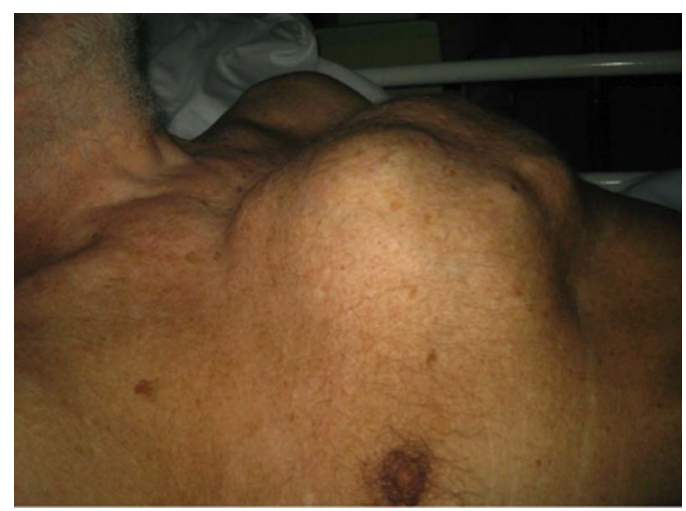

Figure 2 A picture of the sternal mass from the right side.

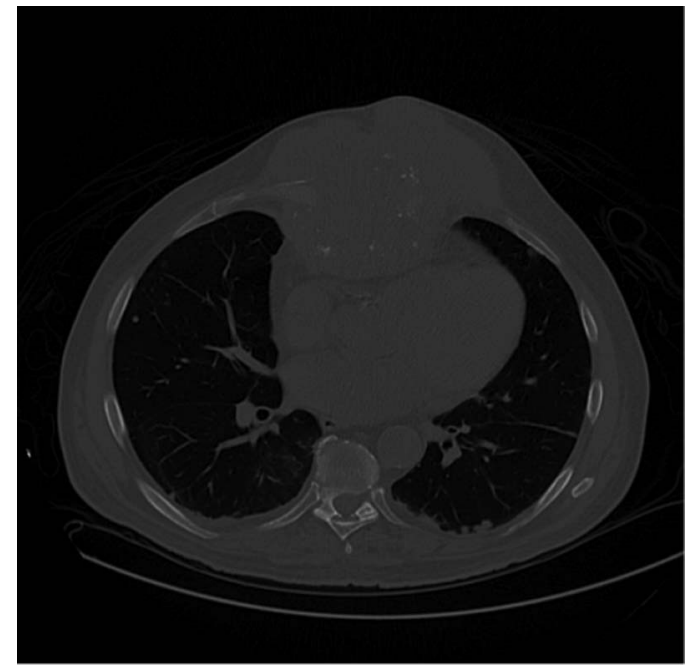

Figure 3 CT of the chest with contrast showing the mass compressing the right ventricle.

\section{Learning points}

- Chordomas are locally aggressive and tend to relapse. A radical resection is paramount to prevent relapse and metastasis.

- Despite the low metastatic potential, metastasis has still been reported, but anterior chest wall is an uncommon site.

Competing interests None.

Patient consent Obtained.

Provenance and peer review Not commissioned; externally peer reviewed. 


\section{REFERENCES}

1 Vergara $G$, Belinchón $B$, Valcárcel F, et al. Metastatic disease from chordoma. Clin Transl Oncol 2008;10:517-21.
2 Komanapalli $C B$, Sterin $R$, Wheatley $M$, et al. Chest wall invasion from metastatic chordoma. The cardiothoracic surgery network. http://www.ctsnet.org/sections/ clinicalresources/clinicalcases/article-15.html (accessed Jan 2013).

Copyright 2013 BMJ Publishing Group. All rights reserved. For permission to reuse any of this content visit http://group.bmj.com/group/rights-licensing/permissions.

BMJ Case Report Fellows may re-use this article for personal use and teaching without any further permission.

Become a Fellow of BMJ Case Reports today and you can:

- Submit as many cases as you like

- Enjoy fast sympathetic peer review and rapid publication of accepted articles

- Access all the published articles

- Re-use any of the published material for personal use and teaching without further permission

For information on Institutional Fellowships contact consortiasales@bmjgroup.com

Visit casereports.bmj.com for more articles like this and to become a Fellow 